\title{
Alhaurin el Grande y Gerald Brenan
}

Keywords: derecho; legislación; jurisprudencia; animal

El nombre de Alhaurín el Grande ha estado asociado, para muchos de nosotros, con el hispanista inglés, miembro del grupo de Bloosmbury, Gerald Brenan (1894-1987). Brenan, autor de algunos de los libros más reveladores y objetivos de nuestro pasado reciente, como The Spanish Labyrinth: An Account of the social and Political Background of the Civil War, publicado en 1943 y cuya edición española, tardó muchos años en ser vendida libremente en nuestro país -había que leerlo en una editorial "prohibida” como Ruedo Ibérico-, es uno de esos personajes atraído por una España anterior a la Guerra Civil, que supo retratar magistralmente. Vivió la mayor parte de su vida en Alhaurín el Grande, formando parte del pueblo, donde le llamaban D. Geraldo y sin perder nunca contacto con sus múltiples amigos de todo el mundo, artistas, literatos, viajeros impenitentes.

Un escritor brillante, un amante de España y de sus tradiciones, como refleja en South of Granada, se hubiera sentido indignado de que su pueblo, Alhaurín, se asocie desde mayo al espectáculo cruel de la muerte de una vaquilla, tras una brutal paliza, por los mozos del pueblo que celebraban las fiestas de la localidad [1] . Sí, D. Geraldo se habría sentido abochornado como cualquiera que contemple -si puedelas imágenes que reatransmitieron las cadenas de televisión en los noticieros y que están ya expuestas en Youtube.

No hay tradición, ni costumbre, ni uso legítimo que persista en tolerar tal barbarie y que la subvencione con dinero público. No es sólo cuestión de la imagen que España proyecta en el exterior -que, desde luego, no es buena-, pues reducir la cuestión a ese aspecto sería, como dicen los alemanes un "Kosmetikbegriff”, un concepto de maquillaje de la realidad. La realidad es más simple y más dura. Es un combinado de brutalidad y de impunidad. Se puede masacrar a un animal indefenso (¿cuantos kilos pesaría la vaquilla, abatida por las hordas de mozos borrachos?), a la vista de todo el pueblo y de los agentes de la policía y de la Guardia Civil, sin que haya peligro, ni tan siquiera de un "alto!”, "parad ya, que la estais matando!”, ni, por supuesto, de una denuncia, de una condena o de una multa. Es de eso de lo que se trata, de brutalidad permitida, consentida, jaleada y subvencionada. Las imágenes están a la vista de todos, las caras de los mozos nítidas. Sólo una denuncia se ha hecho, por parte de un miembro de una sociedad animalista.

Tienen que acabarse los festejos populares en que los animales estén expuestos al sufrimiento. Es una sociedad abotargada, que mira para otro lado, la que consiente que se maltrate a un animal, por mera diversión (sangrienta). Hay que remontarse a fases históricas muy antiguas para encontrar precedentes de tales espectáculos y, aún así, hubo voces de filósofos, de pensadores, que clamaban porque se pusiera punto final al maltrato animal. El Derecho, en vergonzoso silencio, está permitiendo que se continúe con actos que degradan a una sociedad entera.

¿Qué se puede hacer?. ¿Con qué contamos para poner freno a este tipo de actos?. Pues con no mucho, la verdad, aunque importante. De entrada con un colectivo, cada vez más numeroso de ciudadanos que no toleran que se inflija sufrimiento a los animales. Una sensibilidad social emergente, que se opone a verse en el espejo de la crueldad hacia los animales. También con el deseo de muchos padres y educadores de no mirar hacia otro lado y de transmitir a sus hijos, a sus alumnos, que el maltrato animal envilece al ser humano y que nuestra responsabilidad ciudadana, nuestro compromiso con las generaciones futuras, implica también la protección animal, es decir, como se expresa en textos jurídicos de nuestro entorno europeo, implica un compromiso de protección y de respeto por la naturaleza y por los animales, muy 
especialmente. Por ello, en tales países, los animales ya no son jurídicamente “cosas en propiedad”, sino seres sensibles.

En el ámbito jurídico, disponemos, es cierto, de una serie de medios para castigar a quien maltrata a un animal, basta echar una mirada a los artículos 337 y 632 del Código Penal y a las muy numerosas leyes de protección animal de las Comunidades Autónomas, todas ellas bajo el señuelo de proteger al animal y castigar al maltratador. También contamos con una naciente línea jurisprudencial, cada vez más firme, que aboga por una interpretación severa de la norma, que imponga a quien abandone, maltrate o mate a un animal todo el peso de la ley. Pero preguntémonos, qué nivel de eficacia tiene la abundantísima normativa sancionadora. Hasta dónde llega el Derecho en la protección de los animales y de qué forma ese binomio Derecho-Sociedad es eficaz hoy en día y en nuestras fronteras.

Tenemos una carencia que nos aparta de la tendencia de los países de nuestro entorno europeo, que es la ausencia de una Ley General de Protección Animal. Quienes piensen que en un Estado configurado en Autonomías tal ley no es viable, habría que recordarles que en tres de los países donde dicha normativa goza de mayor solera, son precisamente tres estados federales; a saber: Austria, Alemania y Suiza, por lo tanto, no está en principio reñida la existencia de una ley que regule el régimen de protección a los animales de forma estatal, con la promulgación de normas particulares en los distintos ámbitos federados, Länder o cantones. Este modelo sería perfectamente aplicable a España, sin desdoro de la normativa autonómica existente, que quizá tendría, si tal ley general existiera, que adaptarse para, por ejemplo, adoptar una denominación común para los animales de compañía, que también se denominan domésticos, de abasto o renta, lo que no produce sino confusión a la hora de consultar la normativa vigente y también alejamiento de la norma del usuario, o del responsable de la aplicación de la misma.

No se trata, pues, sólo de una reforma para endurecer las normas penales contra el maltrato animal, que también sería necesaria; sino, más bien de una acción coordinada en un doble frente. Uno, dar respuesta a la ciudadanía que se siente cada vez más sensible ante el maltrato, incluyendo en la formación ordinaria en las escuelas una pedagogía de la compasión hacia los animales. Otro, responsabilizar a los operadores jurídicos, de promover la aplicación íntegra de las penas contra el maltrato animal y de iniciar los cambios oportunos para dotar a los animales, en la norma regente de nuestro sistema jurídico, del reconocimiento de éstos como seres sensibles y no como cosas.

En los países en donde dicho cambio de estatuto jurídico se ha producido, el efecto es patente y notorio. Tanto en la vida social, pues hay mayor tolerancia a la presencia de los animales en el ámbito ciudadano, el abandono disminuye, la responsabilidad de las nuevas generaciones se afina; como en el ámbito de las normas, pues éstas se aplican y crece la responsabilidad y lo que se conoce como la "cultura de la denuncia”. No se mira con indiferencia hacia otro lado ante el maltrato animal, los ciudadanos toman la iniciativa y son los que se deciden a cambiar las cosas, para que no vuelvan a ocurrir actos que denigran, por su crueldad, a una sociedad en su conjunto.

En los años sesenta, en plena revolución de la moda, de la música, de las costumbres y hábitos sexuales, en Gran Bretaña se publicó un libro titulado “Animal Machines: The new Factory Farming Industry”, cuya autora, Ruth Harrison, galvanizó con su escrito a la sociedad británica, acerca de la penosa situación de explotación de los animales en las granjas de producción masiva de carne, un fenómeno, novedoso en aquel momento, cuyo conocimiento generó una alarma social, que desembocó en la creación de una Comisión en el Parlamento para la defensa y protección de los animales de granja. Dicha Comisión elaboró las llamadas “Five Fredoms”, en defensa de unas condiciones mínimas de hábitat de los animales, que han servido de guía para la posterior legislación de Bienestar Animal en el ámbito de la Unión Europea.

Este es, definitivamente, un buen ejemplo de cómo Derecho y Sociedad actúan sinérgicamente. No en vano, Gran Bretaña goza del honor de haber promulgado la primera ley de protección animal, nada menos que en 1802. Desde entonces, la permeabilización entre las normas y los hábitos de la entera sociedad británica, no han cejado en su empeño por proteger cada vez más eficazmente a los animales; Gerald Brenan, habría presentado, seguro, una denuncia en su pueblo, en Alhaurín el Grande. 
Teresa Giménez-Candela

Catedrática de Derecho Romano. UAB

Presidenta de AIUDA

[1] Publicada en El Mundo, Link externo 